\title{
PENGETAHUAN IBU PADA PENATALAKSANAAN BBLR DI RSUD DR. SOE K ARDJO KOTA TASIKMALAYA
}

\author{
Ima Sukmawati, Yuyun R ahayu, Irma M ardiana \\ STIKes M uhammadiyah Ciamis \\ E mail: imasukmawati90@ yahoo.com
}

\begin{abstract}
ABSTRAK
Latar Belakang. Bayi berat badan lahir rendah (BBLR) adalah bayi lahir dengan berat badan kurang dari 2500 gram. Jumlah BBLR di RSUD dr. Soekardjo Kota Tasikmalaya (2016) di ketahui pada bulan J anuari 2015-Maret 2016 adalah 202 kejadian. Dampak dari BBLR akan terjadi gangguan pernafasan, gangguan nutrisi dan mudah terkena infeksi. Tujuan penelitian Mengetahui pengetahuan ibu pada penatalaksanaan BBLR di RSUD dr. Soekardjo Kota Tasikmalaya 2016. Metode Metode menggunakan deskriptif. Populasi adalah ibu yang melahirkan BBLR sebanyak 35 responden dengan tehnik accidental sampling. Hasil. Penelitian menunjukkan pengetahuan penatalaksanaan BBLR baik sebanyak 1 orang ( 2,9\%), cukup sebanyak 11 orang (31,4\%), dan kurang sebanyak 23 orang (65,7\%). Simpulan. Pengetahuan ibu pada penatalaksaan termoregulasi didapatkan hasil kurang dari 24 orang $(68,6 \%)$, penatalaksanaan nutrisi sebanyak 20 orang $(57,1 \%)$, pencegahan infeksi kurang dari 21 orang $(60,0 \%)$, dan pengetahuan ibu kurang dari 23 orang $(65,7 \%)$.
\end{abstract}

Kata Kund: penatalaksanaan BBLR, pengetahuan ibu.

\begin{abstract}
Background Baby has low weight infant is less of 2500 gram when born (Sofian, 2012). Preliminary studies done at Regional Public Hospital dr. Soekardjo Tasikmalaya (2016) told amount BBLR on january in 2015 - march in 2016 is 202 BBLR Cases. The purpose of this study is to now about desciption of mother's knowledge in management of BBLR at Regional Public Hospital dr. Soekardjo Tasikmalaya 2016. Method. The method of this research is descriptive method. It's population is mother who give BBLR birth counted 35 respondents by using accodental sampling technique. Result Management of BBLR at Regional Public Hospital dr. Soekardjo Tasikmalaya in a good category is 1 client (2.9\%), middle or enought is 11 clients (31.4\%), and low category is 23 clients (65.7\%).Condusion and suggestion. Mother's knowledge on management of less termoregulation is 24 clients $(68,6 \%)$, mutrision management is 20 clients (57,1\%), les or low inffection prepention is 21 clients $(60,0 \%)$, les or low of mother's knowledge is 23 clients (65.7\%). For Regional Public Hospital dr. Soekardjo Tasikmalaya give counselling countinuosly on mother who born BBLR.
\end{abstract}

Key Wordt Mother's knowledge, management of BBLR

\section{A. PENDAHULUAN}

Angka Kematian Bayi (AKB) merupakan salah satu indikator penting untuk menilai tinggi rendahnya derajat kesehatan masyarakat ${ }^{1}$. Bayi berat badan lahir rendah
(BBLR) yaitu bayi yang berat badannya kurang dari 2500 gram tanpa memperhatikan usia gestasi 2. Bayi BBLR akan mengalami resikoterjadi permasalahan padasistemtubuh seperti, gangguan pernafasan, gangguan 


\section{GASTER Vol. XV No. 1 Februari 2017}

nutrisi dan mudah terkena infeksi karena daya tahan tubuh lemah, kemampuan leukosit masih kurang, pembentukan antibodi belum sempurna, hipotermi dan reflek menyusu yang kurang sehi ngga dapat terjadi gangguan nutrisi ${ }^{3}$.

Penatalaksanaan perawatan pada bayi BBLR yang dilakukan oleh seorang ibu meliputi mempertahankan suhu atau yang di sebut metode kanguru. Metode kanguru di gunakan sebagai penggani inkubator yang efektif dan ekonomis ${ }^{4}$. Menurut Girsang $(2009)^{5}$ metoda kanguru adalah satu upaya yang dilakukan untuk mengatasi berbagai permasalahan pada bayi dengan berat badan Iahir rendah berupa memberikan ASI kepada bayi BBLR di rumah dan pencegahan terjadinya infeksi bayi BBLR.

Hasil study pendahuluan yang di lakukan di RSUD dr. Soekardjo kota Tasikmalaya (2016) menyebutkan bahwa jumlah BBLR pada bulan januari-desember 2015 dan Januari-Maret 2016 adalah 202 kejadian. Mengingat tingginya ibu yang belum mengetahui penatalaksanaan perawatan bayi BBLR dengan angka kejadiannya tinggi, maka perlu penelitian untuk melihat penatalaksanaan yang baik untuk mencegah terjadinya resiko maupun komplikasi lebih lanjutpadabayi BBLR di RSUD dr. Soekardjo KotaTasikmalaya 2016.

\section{B. BAHAN DAN METODE}

Penelitian ini merupakan penelitian kuantitatif, desain yang di gunakan adalah deskriptif yaitu menggambarkan pengetahuan ibu pada penatalaksanaan BBLR. Variabel adalah variabel tunggal yaitu Pengetahuan ibu pada penatalaksanaan BBLR. Populasi dalam penelitian ini adalah semua ibu yang melahirkan bayi dengan BBLR di RSUD Dr. Soekardjo Kota Tasikmalaya pada bulan Juni-Juli 2016.

Dal am penelitian ini, pengambilan sampel menggunakan Accidental Sampling dengan jumlah sampel adalah 35 responden. Kriteri inklusi adalah Ibu yang melahirkan BBLR di RSUD dr. Soekardjo Kota Tasikmalaya, sedangkan kriteria ekslusi adalah ibu yang melahirkan bayi normal di RSUD dr. Soekardjo Kota Tasikmalaya.

Teknik pengumpulan data dengan menggunakan accidental sampling yaitu bahwa setiap anggota atau unit popul asi yang datang dan memenuhi kriteria inklusi masuk dalam sampel penelitian sampai dengan jumlah sample terpenuhi yaitu dalam kurun waktu penelitian yang telah di tentukan. Instrumen penelitian adalah angket. Angket berbentuk formul ir yang berisikan pertanyaan (question). Tahap persiapan diawali dengan melakukan survey pendahuluan untuk mendapatkan data dasar yang diambil dari RSUD dr. Soekardjo kota Tasikmalaya.

Tahap pelaksanaan penelitian antara Iain: mendapatkan izin untuk penelitian, menentukan dan membuat kejjasama dengan petugas kesehatan ditempat penelitian, menjelaskan maksud penelitian kepada responden, melakukan pengumpulan data dan analisa data menggunakan teknik komputerisasi. Setelah data dientry dan dianalisis, dilakukan penyajian hasil 
pengol ahan data dan di interpretasikan bentuk laporan, dilakukan pembahasan dari temuantemuan penelitian, menarik kesimpulan serta membuat saran atau rekomendasi mengacu hasil penelitian yang telah dilakukan.

Metode pengolahan data yaitu, pemeriksaan data (Editing data), pemberian kode (Coding), pemasukan data (Entry data) dan tabulating. Analisis data menggunakan anal isaunivariatyang menghasi lkandistribusi dan presentase dari tiap variabel yang diteliti. Etika penelitian dengan menggunakan prinsip manfaat, prinsip menghargai hak asasi manusia (respect human dignity), dan prinsip keadilan.

\section{HASIL DAN PEMBAHASAN}

Dari hasil pengumpulan data gambaran pengetahuan ibu pada penatal aksanaan BBLR di RSUD dr. Soekardjo Kota Tasikmalaya adalah sebagai berikut:

Pengetahuan ibu pada penatalaksanaan termoregulasi pada BBLR

Tabel 1. Distribusi penatalaksanaan termoregulasi oleh ibu

\begin{tabular}{ccc}
\hline $\begin{array}{c}\text { Penatalaksaan } \\
\text { termoregulasi }\end{array}$ & Frekuensi & Presentase \\
\hline Baik & 3 & $(\%)$ \\
Cukup & 8 & 22,9 \\
Kurang & 24 & 68,6 \\
\hline Total & 35 & 100.0 \\
\hline
\end{tabular}

Berdasarkan tabel 1. menunjukkan 24 orang $(68,6 \%)$ kurang dal ampenatal aksanaan termoregulasi pada BBLR, yaitu tidak melakukan metode kanguru atau menjaga ruangan bayi tetap hangat. Penyebabnya dikarenakan tingkat pendidikan rendah, dimana mereka tidak mengetahui bagaimana cara termoregulasi BBLR yang baik. Didukung Ismawati (2010)6 faktor yang mempengaruhi pembentukan perilaku adalah pemberian informasi, pendidikan dan pekerjaan. Petugas kesehatan juga ikut bertanggungjawab dalam memberi sebaran informasi mengenai BBLR. Tidak adanya sinergis antara ibu dengan petugas kesehatan, menyebabkan penatal aksanaan termoregul asi tidak berjalan.

Pengetahuan BBL Ribu pada penatalaksanaan nutrisi pada BBLR

Tabel 2. Distribusi pengetahuan ibu pada penatalaksanaan nutrisi BBLR

\begin{tabular}{ccc}
\hline Penatalaksanaan Nutrisi & Frekuensi & $\%$ \\
\hline Baik & 20 & 57,1 \\
Cukup & 11 & 31,4 \\
Kurang & 4 & 11,4 \\
\hline Total & 35 & 100.0 \\
\hline
\end{tabular}

Hasil tabel 2. pengetahuan ibu tentang penatalaksanaan nutrisi adal ah baik sebanyak 20orang(57,1\%). Hasil menunjukkansebagian besar responden melakukan penatal aksanaan yang baik meliputi memberikan asi dan mengetahui cara menyusui yang benar. Hal ini di karenakan, ibu melakukan perawatan dan menyusui secara langsung pada bayinya sehingga mereka mendapatkan pengalaman secara langsung. Khosim dkk (2010) ${ }^{7}$ mengatakan pendampingan dari tenaga kesehatan, orangtua dan lingkungan yang

Pengetahuan I bu pada Penata ... 55 


\section{GASTER Vol. XV No. 1 Fedruari 2017}

mendukung juga ikut berpengaruh sehingga penatal aksanaan nutrisi bisa dijal ankan.

Pengetahuan ibu pada penatalaksanaan pencegahan infeksi pada BBLR

Tabel 3. Distribusi pengetahuan ibu pada penatalaksanaan pencegahan infeksi pada BBLR

\begin{tabular}{ccc}
\hline $\begin{array}{c}\text { Penatalaksanaan } \\
\text { pencegahan infeksi }\end{array}$ & Frekuensi & $\%$ \\
\hline Baik & 4 & 11,4 \\
Cukup & 10 & 28,6 \\
Kurang & 21 & 60,0 \\
\hline Total & 35 & 100.0 \\
\hline
\end{tabular}

Pada Tabel 3. didapatkan pengetahuan ibu pada penatalaksanaan pencegahan infeksi sebanyak 21 orang $(60,0 \%)$ dalam kategori kurang. Responden tidak melakukan penatalaksanaan pencegahan infeksi pada BBLR yaitu tidak mencuci tangan. Menurut Rabby dan Dey (2013) praktik cuci tangan dipengaruhi oleh sosial ekonomi, tingkat pendidikan dan akses media televisi. Pengetahuan tersebut antara lain mengenai perawatan bayi BBLR pada aspek mencegah terjadinyainfeksi pada bayi BBLR mencakup 5 hal, diantaranya adalah mengangkat bayi untuk menghindari injuri, mengenal tanda infeksi bayi dan mencegah infeksi, perawatan tali pusat, mengganti pakaian dan popok, pemakaian bedak dan minyak penghangat, penggunaan minyak penghangat seperti minyak telon dan kayu putih harus hati-hati karena dapat menyebabkan luka bakar dan infeksi pada kulit bayi.

Hal ini sesuai dengan teori Bang, A.T
$(2010)^{9}$ dan Wong (2008)2, perlindungan terhadap infeksi merupakan bagian integral asuhan semua bayi baru lahir terutama pada bayi preterm dan sakit. Pada bayi BBLR imunitas seluler dan humoral masih kurang sehingga sangat rentan dengan penyakit. Menunut asumsi peneliti bahwa pencegahan infeksi yang kurang akan mempenganuhi derajat kesehatan BBLR karena padaBBLR imunitas dan organ-organnya belum terbentuk secara sempurna.

Gambaran pengetahuan ibu pada penatalaksanaan BBLR di RSUD dr. Soekardjo kota Tasikmal aya

Tabel 4. Distribusi pengetahuan ibu pada penatalaksanaan

BBLR di RSUD dr. Soekardjo Kota Tasikmalaya

\begin{tabular}{ccc}
\hline $\begin{array}{c}\text { Pengetahuan ibu pada } \\
\text { penatalaksanaan }\end{array}$ & Frekuensi & $\%$ \\
\hline BBLR & & \\
Baik & 1 & 2,9 \\
Cukup & 11 & 31,4 \\
Kurang & 23 & 65,7 \\
\hline Total & 35 & 100,0 \\
\hline
\end{tabular}

Dari hasil penelitain ke tiga item tersebut yaitu pengetahuan ibu pada penatal aksanaan BBLR terdiri dari termoregulasi, nutrisi dan pencegahan infeksi BBLR menunjukkan bahwa frekuensi terbanyak adalah berpengetahuan kurang sebanyak 23 orang $(65,7 \%)$. Pengetahuan sangat ditunjang oleh beberapa faktor ekstrinsik (lingkungan masyarakat, pengalaman orang lain, media masa) dan faktor intrinsik (pemahaman dan pengetahuan, pengalaman pribadinya). 
GASTER Vol. XV No. 1 Februari 2017

Pengetahuan kurang yang dimiliki ibu disebabkan karena tingkat pendidikan ibu adalah SD yaitu sebanyak 15 orang $(42,9 \%)$. Berdasarkan wawancara singkat dengan ibu yangmel ahi rkanBBLR di RSUD dr.Soekardjo kota Tasi kmal aya bahwa kurangnya mencari informasi, memanfaatkan teknologi yang ada baik dari media cetak maupun elektronik sehingga tidak mendapatkan informasi yang lengkap. Dilengkapi hasil kuesioner yang menunjukkan bahwa sebagian besar ibu menjawab salah pada pertanyaan no 13 dan 17.

Di dukung penelitian Prawirohardjo (2010)12, bahwa respon ibu terhadap permasalahan bayi BBLR sangat mempengaruhi keputusan ibu untuk melakukan perawatan terhadap pertumbuhan dan perkembangan bayinya. Banyak ibu belum bisa merawat bayi BBLR sehingga tidak terselamatkan, dikarenakan kurangnya pengetahuanibutentang perawatankhususnya bayi BBLR.

Sejalan penelitian Rita (2010) ${ }^{11}$, pendidikan memberikan andil dalam upaya untuk memberikan pengetahuan sehingga terjadi perilaku positif yang mengikat. Notoatmodjo $(2013)^{10}$ mendefinisikan bahwa pengetahuan adalah suatu hasil dari tahu yang terjadi setelah seseorang melakukan penginderaan terhadap suatu objek tertentu, melalui indera penglihatan, pendengaran, penciuman, perasaan dan perabaan. Sebagian besar pengetahuan manusia di perol eh melal ui penglihatan dan pendengaran, hanya sedikit yang diperoleh melal ui penciuman, perasaan dan perabaan. Pengetahuan tentang kesehatan adalah mencakup apa yang diketahui seseorang terhadap cara-cara memelihara bayi pada BBLR.

\section{SIMPULAN DAN SARAN}

Pengetahuan ibu pada penatalaksanaan BBLR tentang termoregul asi dan pencegahan infeksi hasilnya adalah kurang. Sedangkan pengetahuan pentalaksanaan nutrisi tentang BBLR hasilnya adal ah baik. Literatur tentang peningkatan BBLR perlu ditingkatkan. Sarana dan prasarana alat pelindung diri (APD) dilengkapi serta penyul uhan mengenai penatalaksanaan BBLR perlu diperbanyak.

\section{DAFTAR PUSTAKA}

Merzalia, N. (2012), Determinan kejadian berat badan lahir rendah (BBLR) dikabupaten belitung timur provinsi kepul auan bangka belitung tahun 2010-2011. Depok: FKM UI. Wong, D., Eaton, M. H., Wilson, D., Winkelstein, M., \&Schwart, P. (2008), Buku Ajar Keperawatan Pediatrik (6 ed., Vol. 1), J akarta: buku Kedokteran EGC Elizabeth, J.C (2013), Buku Saku Patofisiologi (3 ed), Jakarta.EGC. WHO (2013). Berat Badan Lahir Rendah (BBLR) : World Heal th Organization.

Girsang, M (2009), Dalamjurnal, Pola Perawatan bayi berat lahir rendah di rumah sakit dan di rumah dan hal-hal yang mempengaruhinya. 


\section{GASTER Vol. XV No. 1Februari 2017}

Ismawati, Proverawati (2010), Berat Badan Lahir Rendah (BBLR), Yogyakarta: Nuha Medika KhosimS, Indarso, dkk (2010), BukuAcuan Pelatihan Pelayanan Obstetri Neonatal Emergensi Dasar, Dep.Kes. RI.

Bang AT, Bang RA (2010), Low Birth Weight and Preterm Neonatus: Can they managed at home by mother and a trained village health worker. Journal of Perinatology.

Rabbi, E.S , Dey, N.C. (2013), Exploring the gap between hand washing knowledge and practices in Bangladesh: a cross-sectional comparative study.BMC Public Health.

Notoatmodjo,S, (2013), Metodologi Penelitian Kesehatan, Rineka Cipta J akarta.

Rita Magdalena Baru Tarigan (2010), Pengetahuan Ibu Tentang Penatal aksanaan Perawatan Bayi BBLR di Rumah di RSKIA Kota Bandung.

Prawirohardjo, Sarwono (2010), IImu Kebidanan, Jakarta: PT Bina Pustaka Sarwono Prawirohardjo. 